\title{
Conferences on New Political Economy
}

\author{
Vol. 25: Scientific Competition \\ Ed. by Max Albert, Dieter Schmidtchen and Stefan Voigt
}

[Wissenschaftlicher Wettbewerb.]

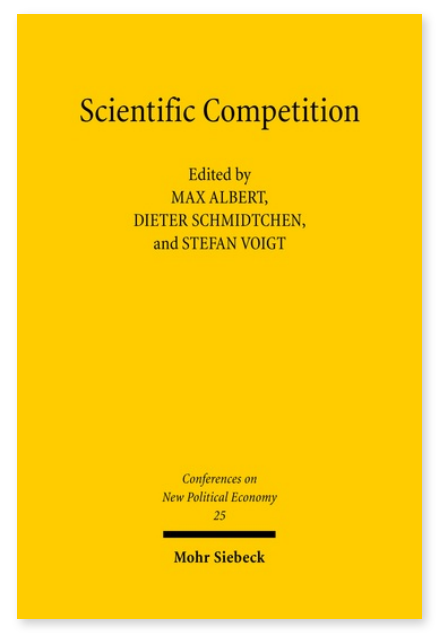

2008. VI, 317 Seiten.

ISBN 978-3-16-156037-8 DOI 10.1628/978-3-16-156037-8 eBook PDF

ISBN 978-3-16-149413-0

Leinen $179,00 €$
Veröffentlicht auf Englisch.

Ist die Wissenschaft ein 'Markt der Ideen'? Nach Meinung der Wissenschaftsökonomen: nein. Die Wissenschaft ist ein Wettbewerb, aber der wissenschaftliche Wettbewerb ist kein Marktwettbewerb. Auch bedeutet wissenschaftlicher Wettbewerb nicht dasselbe wie Wettbewerb zwischen den Universitäten. Autoren verschiedener Disziplinen werfen in dem vorliegenden Band neues Licht auf viele Aspekte des wissenschaftlichen Wettbewerbs, vom akademischen Arbeitsmarkt bis zur Verfassung der Wissenschaft.

Dieser Titel wurde im Open Access im Rahmen der Knowledge Unlatched Select Runde 2018 durch zahlreiche teilnehmende Bibliotheken ermöglicht.

Inhaltsübersicht

Max Albert: Introduction - Paula E. Stephan: Job Market Effects on Scientific Productivity - Bernd Fitzenberger: Comment Günther G. Schulze: Tertiary Education in a Federal System. The Case of Germany - Stefan Voigt: Comment - Gustavo Crespi/Aldo Geuna: The Productivity of UK Universities - Christian Pierdzioch: Comment - Michael Rauber and Heinrich W. Ursprung: Evaluation of Researchers. A Life Cycle Analysis of German Academic Economists - Werner Güth: Comment Martin Kolmar: Markets versus Contests for the Provision of Information Goods - Roland Kirstein: Comment - Christine Godt: The Role of Patents in Scientific Competition. A Closer Look at the Phenomenon of Royalty Stacking - Christian Koboldt: Comment - Nicolas Carayol: An Economic Theory of Academic Competition. Dynamic Incentives and Endogenous Cumulative Advantages - Dominique Demougin: Comment - Dorothea Jansen: Research Networks - Origins and Consequences. First Evidence from a Study of Astrophysics, Nanotechnology and Micro-economics in Germany - Henrik Egbert: Comment Christian Seidl, Ulrich Schmidt, and Peter Grösche: A Beauty Contest of Referee Processes of Economics Journals - Max Albert/Jürgen Meckl: Comment - Jesús P. Zamora Bonilla: Methodology and the Constitution of Science. A Game-theoretic Approach - Gebhard Kirchgässner: Comment - Christian List: Distributed Cognition. A Perspective from Social Choice Theory - Siegfried Berninghaus: Comment

Max Albert Geboren 1959; 1992 Dr. rer. pol. und 1998 Habilitation an der Universität Konstanz; 1998 bis 2003 Professor für Wirtschaftswissenschaft an der Universität Koblenz-Landau in Landau; 2003 bis 2007 Inhaber des Lehrstuhls für Wirtschaftstheorie an der Universität des Saarlandes; seit 2007 Professor für Verhaltens- und Institutionenökonomik an der Justus-Liebig-Universität Gießen.

Stefan Voigt is a professor at the University of Hamburg and director of the Institute for Law and Economics at the University of Hamburg, fellow of the CESifo in Munich and connected to the International Centre for Economic Research (ICER) in Turin.

Dieter Schmidtchen holds the chair for Public Policy and Managerial Economics at University of the Saarland and is director of the Center for the Study of Law and Economics, Saarbrücken.

Jetzt bestellen:

https://mohrsiebeck.com/buch/conferences-on-new-political-economy-9783161560378?no_cache=1 order@mohrsiebeck.com

Telefon: +49 (0)7071-923-17

Telefax: +49 (0)7071-51104 